\title{
Surveying Location Pattern of Nabi Mosque According to Verses, Hadithes and Prophet's Sira
}

\author{
Parisa Gorbannejad and Fatima Jalilzadeh Mohammadi
}

\begin{abstract}
One important characteristic of Islamic culture is issue of architecture that has undergone an evolutional process in dealing with neighboring civilizations with a supplementary role. In Prophet's (PBUH) time and Saudi Bedouin, Islamic architecture began its own identity by establishing Prophet's Mosque in Medina without any Special glaze and decoration but full of eternal concepts. This building is considered in different aspects and this article deals only with one aspect which is subject of mosque location according to the prophetic pattern of Islamic urbanization in an analytic and comparative method (comparing Verses and Hadith with the Prophet's Sira). Although the location of prophet's mosque was affected by geographic environment and Saudi Arabian native culture, it matches with paradigms of Quran and Hadith. Furthermore, it was built by divine order and consideration of characteristics such as: dominances of the urban space, centrality, extensibility and retrofitting, independence, invitation, unity and absorbing the majority, universality, material and spiritual prosperity and development, compatibility of mosque's neighborhood functions, cleanness, ideality for prayer and spiritual comfort, rights of land owners, and etc. This article intends to investigate the characteristics of location of mosques on the base of verses and Hadith and compare result with Prophet's Sira.
\end{abstract}

Index Terms—Location, medina, NABI mosque, quran.

\section{INTRODUCTION}

Migration of Prophet (PBUH) was the beginning of a fundamental change in the structure of Islamic civilization which met its civility combined with the growing rule. Accordingly, Prophet (PBUH) as a divine and smart leadership established a new system to achieve the ideals of Islam and moved toward forming a government for which focusing on the material and spiritual forces in a varied and comprehensive framework were necessary. A new Bondage building included the name of Medina in addition to the name of mosque, due to its special function. This was due to its significant role in entering to a religious civilization and its sustainable development. Because of the sensitive nature of early Islamic civilization and its identity, it seems that this place has had a cumulative account of a particular location as a base and of Islamic civilization, in which the Messenger of Allah (SAW) introduces the ideology of Islam. Theoretical and practical aspects of Islam, including the Quran, Hadith,

Manuscript received June 9, 2014; revised August 28, 2014.

Parisa Gorbannejad is with Urmia Free University, West Azarbayjan, Iran (e-mail: gorbannejad@gmail.com).

Fatima Jalilzadeh Mohammadi is with Najaf Abad Free University, Isfahan, Iran (e-mail: E.psych.arch@mail.com).
Prophet's (PBUH) Sira and rationality were influential in choosing this location. With this assumption, the way Nabi Mosque was located to introduce it as a comprehensive and an optimum model in the structure of Islamic cities, its cultural importance in guiding the development of cities toward those Islamic orders, and factors influencing the location of this mosque should be investigated.

It must be said that there was not any intellectual, practical and physical space of today's Islamic city, in Yathrib. Prophet Mohammed's migration affected various aspects of people's life. The first change in local pattern was $N a b i$ Mosque. This physical change, changed intellectual and practical space of Yathrib and converted it to the first city in which the Islamic worldview was founded and the Islamic state came into existence. The main role of the mosque was a center for worship, later it was developed to a religious, political and social center, and because of its significant influence in the area, Yathrib, was converted to the most holy city that was called Medinat An-Nabi.

The aim of this study is to identify the views of Prophet about the location of Nabi Mosque in Medina, through the implementation of verses of Quran and traditions and to provide criteria of optimal locations for mosques. Since Quran introduces Prophet (PBUH) as the best pattern of life style (33:21), to gain accurate insight about his performance, it is required to know practical logic of his life in the main context of Medina, using the historic context, with Nabi Mosque centrality, and its historical changes .As a result, the effects of Prophet's human life last and survive.

The independent variables in this study are the input variable of principles of Islam that are divided into two parts of theoretical (Quran and Hadith) and practical (Sunna and Sira) used to observe and examine their impacts on Prophet's views about the location of Nabi Mosque. It should be said that, based on the historical evidence, other variables have been also involved about the location of Nabi Mosque by Prophet Mohammed (PBUH), however, by limiting their impact on his views, the actual outcome of the two abovementioned variables can be achieved.

This study is based on a historical analysis and the data is collected by using library resources and direct observation of the remained vestige of the Prophet's (PBUH) time.

\section{Methodology}

In an analytic and comparative method Verses and Hadith will be compared with the Prophet's Sira to investigate the characteristics of location of mosques. 


\section{LITERATURE REVIEW}

There is not any independent research conducted so far on the topic of Nabi Mosque location, but few publications that have been written relating to this topic that are reviewed here:

\section{A. Books}

Two books are written about this subject, the textbook of introduction to history of holy sites in Mecca and Medina by A. Ghaedan, published in Tehran, 1389 by Mashar publication. The author has discussed about socio-ethnic composition, geographical features of Yathrib, at Prophet's arrival and his decision of mosque construction and establishment of Islamic civilization. The author discusses events in detail as they were the base of historical sources of Medinology. However, he has not mentioned anything about analyzing the accuracy of narrated events at the time of mosque construction and the establishment of Islamic civilization in this book.

In the book of Mosque of Prophet, which was written by Naji Mohammed Ansari and Abdalqader Hasan, published in 1385 in Tehran, the authors describe Nabi Mosque features in six seasons. They first describe the reasons of building Nabi Mosque, and then express its construction and development in five stages. They mention that Islamic civilization was established by a mosque that had been built on righteousness. Although they have mentioned the events of the period, they have not analyzed that narrative to achieve the implicit concepts and still lag behind.

\section{B. Articles}

The article "A study about the location of mosques in Medina during Prophet Mohammad's (PBUH) era: an introduction to principles for determining proper locations for mosques in Islamic cities" is another related paper written by Mohammad Reza Ataei Hamedani in Nazar journal in the spring of 1390. In this paper, the important principles of location are introduced based on Islamic values and it has been aimed to offer a model of the location of mosques of that era after addressing the urban structure of Medina and achieving the location method of Nabi Mosque. Addressing the garden-neighborhood structure of Medina of the pre-Islamic period, its tribal structure and also its particular climate, it can be concluded that unity, as the most important principle, has made a balance between various factors of location. In addition, the body of the mosques of the period, even the Prophet's mosque, was not the index of city, but was the functional center of neighborhood in that period. The author has divided the mosques into two types of local and public (Jameh) and has considered physical and social structures of cities in their location. Furthermore, he has mentioned Hadithes that relate to the location of mosque and their sanctum in Prophet Mohammed's Sira. But, he has not addressed any divine criteria in Quranic verses. Prophet Mohammed has introduced two important sources: Quran and his Sira that should not be ignored to achieve the principles of Islamic civilization for which Medina was its center.

In another article entitled "Some observations on Islamic architecture and instruction on its revival" by Spahic Omer in a Conference printed booklet that was held in Iran, the revival of Islamic architecture is mentioned by the author. He refers to the important role of Nabi Mosque and Prophet's attempt to revive Islamic architecture by inviting major and coordinate efforts of a wide range of community. On the other hand, he has the main responsibility as the custodian. Prophet Mohammed created the concept of Islamic ethics of architecture and developed it practically and gave ethical nature to architecture as one aspect of Islamic civilization, by building Nabi Mosque. In this paper, he has mentioned general concepts that are evident in Prophet Mohammed's Sira based on which the ethics have been formed, but it seems that Islamic concepts which guarantee ethics in Islamic concepts, have not been mentioned.

In the article, Some lessons from Prophet Mohammed (PBUH) in architecture: the Prophet's Mosque in Medina, that was written in Intellectual Discourse journal, volume 18 the First issue, and published in 2010, writer has reviewed Prophet's experiences of involving in problems of building Nabi Mosque; such as meaning and significance of Islamic architecture, its form-function relationship, respect for nature and cleanliness, overall growth and promoting social activities, and the relationship between indigenous and non-indigenous people in the Islamic community. Furthermore, he has mentioned that Prophet has entered architecture to three grounds of physical, sensual, spiritual and proposed it as a reason of unity in diversity, unity of message and purpose, diversity and species problem and the solution.

In an essay, called "Architecture of mosques and buildings in Prophet's time" that was published in Hajj Rendezvous Magazine, the fifteenth year, the spring 1386, Issue 59, in pages 120-144, the writer describes the architecture of Prophet's time in two sections of mosque and building construction. He mentions that the architecture of that time that was plain without any ornament, relates to the character of the period of Ignorance. Building of mosques and worship places, such as Ghoba and Nabi Mosques indicates the evolution in this context.

\section{LOCATION OF MOSQUES BASED ON ISLAMIC THEORETICAL FOUNDATIONS}

\section{A. On the Base of Verses}

Since mosque in Islam is a major cultural monument, so terms of location, builders and construction types, have been conveyed in many verses of Quran. They are discussed below:

1) First: Before locating and building, the faith, piety and virtue should be its builder's intention. Because the builders' belief and vision includes their religious and social mission and architects faith and truth as a mirror that reflects divine spirit in sacred space of mosque. Furthermore, Islamic architecture before displaying the strength and beauty is the carrier of principles and meanings that creates the essence of Islamic architecture influencing the construction of Muslim cities and a new design of the body and soul and the foundation of Islamic civilization. Since Nabi Mosque was the first and most important place to start the Islamic regime, God decreed the soul of evil to govern the entire building, from its making place to the inner space to become the 
confirmation of "founded on piety" (9:108). The location of mosque is a divine affair, because "Divine guidance filled houses which Allah has given permission to be raised and praised and the name of Allah be remembered in purity (24:36) and the mosques can be raised and held with grandeur where God has allowed only "(24:35). Taking this intention into account, it is so important to note that the construction of mosques is prohibited by hath and even repairing the mosques should be done only by the ones who believe in God and the Day of Judgment $(9: 17,18)$ because all the components and dimensions of a mosque should be with the spirit of faith and this is the first cleric origin of mosque.

In addition, in Dala'il on-Nobovvah it is stated that: "Prophet along with his Companions was carrying clay bricks \{and whispering poetry\} these were useful loads, Our Lord is cleaner and better than the all." [1] The lyrics suggest Prophet was considering the lofty goal of unity even when at work.

2) Second: Since the main purpose of man's creation is to worship (51:56) and the Holy Quran has insisted on aspects of worship than any other aspect, then in the location of mosque as the best and the most original place to worship and closeness to God, it has been mentioned that the Barriers should leave its development and prosperity $(2: 114)$ to prevent the destruction of mosques (22:40). It is not only physical destruction, but the deficiency of mosque is the manifestation of the loss of its development. Thus, according to the physical symptoms, planning activities and adapting them to the principles of localization of worshiping places, the important defining identities of the mosque will affect the environment and attract people.

3) Third: Considering the cleanliness of the environment emphasized in Qur'an, $(2: 125)$ the inside and outside of the mosque should be clean because worship and cleanliness are joined together and clearing is one of the targets of mosque building. Mosque should be built in a place without any obstacle for pure worship and be clean of dirt and filth and be in an ambient air and clean environment without causing resentment as possible. Then, in choosing the location of mosque, its proximity should be noticed to be compatible with, and inducing the Unity of God (72:18). Furthermore, it is stipulated that the location of mosque should fit with dignity and poise believers and the right seekers not to be unaware of God's creatures (humans) or not to live in a mosque neighborhood and obstacle the devotion with their hypocrisy and provocative behavior.

4) Forth: Mosques should be built in high places and their entrance should be down to dominate the city. It makes the sense of humility and reverence when entering the mosque (17:80). Perhaps this is an order to show the grandeur of holy places or symbols of the Islamic state that the mosque are seen all over the city and be dominant in neighborhoods. Then, the city with this context will have a greater spirituality. To prostrate the height of humility and poverty in praying, this character is very important in choosing the location and building mosques.
5) Fifth: Mosques should be possibly built on land where significant historical events occur (18:21) and named as important events such as Ghoba, Salman, Ohod and $A h z a b$. This may be for honoring of mosque or to make it for the users an effective mental memory to remember the God's Days, the day of victory of right over wrong. [2]

6) Sixth: It should be prohibited to build a mosque in a place that requires harm to the rights of others $(9: 109)$. God emphasizes others rights such as respecting the privacy in location of mosques, not seizing property and not harming others physically or mentally before and after mosque construction.

\section{B. Based on Tradition}

Hadithes that are about the location of mosque and physical space around it include: not to locate the mosque building on passageways [3]. However, this order is not general and there are exceptions [4]. It is better to build mosques next to ways and not to block up the passageway nor to prevent the routines. [5]

Another point that has been noted and emphasized by Hadithes is choosing the mosque location with the possibility of future development [6]. It has been said that it is better not to construct any building in mosque's proximity and the area of mosque should be preserved in favor of the mosque. Next in order, in another hadith on the privacy of mosque, it is highlighted that houses should be built with the extent of 40 meters and 40 houses [7]. It seems that the space allowance of mosque was done according to the rate of population in town and neighborhoods. [8]

Hadithes insist on choosing mosque location with facility of accumulation in damage and risk times, moral or physical damages. Because in Hadith it is said that:"Whenever damage and pests come down, the people who are in mosques are safe". This should be sought in people's serenity and stability of mosque. [9]

A highlight of mosque location is the possibility of easy access to the mosque and the accessibility for people to walk to the mosque. This means that the mosque should be build in Muslims neighborhood as near as possible to Muslims to get the benefits of walking toward the mosque [10]. In a city, each neighborhood should have a mosque in its center.[11] And women's security should be provided for their circadian presence in mosques. [12]

In choosing the location, lack of noise pollution has been insisted in Hadithes. The mosque should be located in a place that outside or inside views of the mosque do not dominate the worship space [13]. All of the above points suggest that mosque building follows certain religious principles that need institutionalization and culture.

\section{PROPHET'S CRITERIA IN NABI MOSQUE LOCATION}

In this section, Prophet's performance is investigated and compared with above principles as the result section.

\section{A. Nabi Mosque and Its Construction Reasons}

Prophet Muhammad (PBH) built Nabi Mosque in the First A.H that was as equal as Haraam Mosque in sanctity [14]. Worshipping was its physical function, but in the 
metaphysical function, moral and spiritual aspects, were signs of all the secrets of Islamic architecture [15]. On the philosophy of Nabi Mosque and Prophet Mohammed's (PBUH) purpose of its establishment, different opinions and views have been expressed in resources that are divided into three sections:

The first and dominant point of view is that Prophet Mohammed's Bayt [16] was built with the aim of new Islamic society and the building had been ordered, not without any planning [17], strong historical narratives support its use according to the daily rites. On one hand, Prophet Mohammed's (PBUH) centrality as the source of all political and partisan developments made that home to the first Muslims, and on the other hand, it was a political and worship center. [18]

The second point of view is that Prophet's home was not built as a worship place [19], but it was place for his life, because he used to go to a vast Mosala outside of Medina, that was a holy area for the divine religion in the past, for holding important Ceremonies and feasts [20]. This point of view considers Prophet's home as a private Muslims association place to solve their problems (33:53), which later became the base of worship and the happenings that changed it into a shrine.

But the third point of view, emphasizes that Prophet built a separate mosque near his home [21] which shows Muslims understanding that regarded it as a new building, of course not in terms of natural and physical appearance, but rather as a gathering place for believers. Perhaps this is the best view that in the first years of Prophet Mohammed's (PBUH) migration (Hegira) his house had changed to the Believers center that had all of architectural functions totally in Medina [22]

\section{B. Surveying Prophet's Sira in Nabi Mosque Location}

Knowing that the best guidance is the guidance of God and the fact that Prophet used his camel with God's permission to locate the mosque (23:29), the criteria considered in this guidance to form the pattern of mosque building in Islamic cities should be studied. It seems that Prophet considered environmental, cultural and social factors certainly in $\mathrm{Nabi}$ Mosque location, because the location of mosques in cities were also affected by cities status.

\section{1) Location aimed at attracting maximum and unity}

The people of Medina had other groups like pagans, Jews, and hypocrites, in addition to the Ansar Muslims, who theologically and politically used every opportunity to undermine Islam as opposition groups. Thus, the location of mosque that was the center of government had to be quite rational and deliberate in order to balance among social groups living in the city of Medina. The depth of tribal prejudices [23] was the lateral cause to choose the mosque location which had to be carefully decided by Prophet. Being an agent of camel was an important action to invite the opposition groups to call for unity and communion in the city to show that Prophet did not advocate a certain group. Prophet's noticing of demographic structure of the city in mosque location and his aim in creating a balanced and harmonious atmosphere of unity were the causes of consolidating religious identity and social relations.

\section{2) Ignoring the factors of power and wealth in location (noticing low land)}

Since mosque is a place of worship; it should not be pollute as a precious place to worldly affairs. [24] The place that was selected for mosque location was a space for drying dates and a stable [25], An area where some palm trees and the tombs of the idolaters were there [26]. In fact, mosque location was chosen due to its religious and social prosperity not materially valuable land. The site of Nabi Mosque was in the arid region that did not have any certain land-use, with a non-significant and margin status, and did not belong to those in power nor wealth. In fact, the principle of spiritual freedom from the constraints of all the peers was considered in choosing location so that the invite toward religion could be done independently and not under dominance of the powerful.

\section{3) Not land grabbing (noticing legislation criteria)}

It was said that Prophet had bought the land at the price of ten dinars, despite its owner's insistence to donate it to Prophet. [27] On the other hand, Prophet sought the transaction of that site to build his house and mosque in it. [28]. It shows that Prophet paid attention to people's rights and land owners consent to avoid worshiping in a place that was forcibly seized. Even the development of the mosque was along with the consent of the property owners and nothing; even the Muslims interest could hinder the condition of getting the consent of owners.

\section{4) Location with the purpose of dominance to the city texture and criteria of centrality}

The house of Prophet was constructed in a central valley on a high spot. From this area, all Medina was visible [29]. This choice was made quite intelligently because the population of Medina was distributed in a semicircle form from Ghoba mosque in South West to Jorof in North West of Medina, so with choosing this location demographic features of population was met. [30]

\section{5) Location with the possibility of development and strengthening}

Prophet Mohammed determined the mosque border on earth with a spear and a line when designing a mosque and divided the site to two sections of worship and living. In a sense, the materialistic and spiritual aspects of life or religion and the world were joined together. Then, he ordered land division and distribution of space for the construction and building and houses, developing them in length, width and height. [31]

Till the seventh year of Hejira, nothing had been changed in the composition and dimensions of Nabi Mosque, but later it was necessary to develop the mosque because of increasing number of Muslims. Initially, the soil of Merbad - the land that was selected for mosque building used as a stable -was loose, the foundation was built with two rows of rocks [32], Palm tree trunk was placed as the holder in certain distances on it and distances between them were filled with adobe.

But at the time of mosque's development, adobe was replaced with bricks. In addition, the number of pillars of the mosque which were eight at the beginning, increased to two rows of 14 columns in Qiblah side. Four pillars of Soffah 
remained in their place and new ones were installed near the old ones [33]. Thus, the area of the mosque was doubled in " 136 cubits $\times 114$ cubits" forming a rectangle shape. [34]

\section{6) Location with regard to the compatibility of neighbor}

Prophet built two connected houses near the mosque for his wives [35]. Nabi Mosque had three doors. One was on the southern wall, another was on the north of the western wall and the third door was in the middle door of the eastern wall. After the change of the Qiblah from Bayt-al-Moghaddas: Jerusalem - to $\mathrm{Ka}$ ' bah (from the north to the south) a door was opened in the north and the southern one was closed. Later on, the number of houses was increased around the mosque. Each of the Companions that had ability built a house near the mosque, and the Immigrants (Soffah Companions) built a room in the mosque yard. Prophet's relatives built rooms behind the mosque yard as well and each of them opened a door to the mosque. After a short time, Prophet (PBUH) ordered to close all the doors except for the door of his daughter's home [36]. The analysis of the concept of Bayts in Quran shows that the only house that had the features of Bayt was his daughter's home and had the merit of proximity with Nabi Mosque.

\section{7) Location with regard to indigenous criteria}

The building of Prophet's shrine and mosque was simple and light the same as primitive and nomadic life of desert-living Arabs, with the combination of palm trees, showing a good example of abstract and unusual wandering architecture and unity, without any distinction [37]. The components and elements of the architecture context of the Medina before Islam was based on the identity of the local area and construction of Otoms (Castels built by Jews). After mosque construction, Prophet did not permit the destruction of Otoms saying that they are adornments of Medina [38]. Due to bad weather, sun and harsh winds, Medina residents of all classes made Areesh (It is an Arabic old word and means: Awning made of tree branches and wood to protect from heat and sun; heap; cottage) which was well known to Prophet .Of course, Areesh was linked to agricultural activities at that time, a place for farmers rally to harvest, and Prophet used it to create unity among inhabitants of Medina. [39]

\section{8) Location based on cleaning criteria}

Prophet considered several factors of cleanliness in choosing the location of Nabi Mosque and its proximity. The first was to reduce pollution caused by floods and river flooding. Prophet located mosque on a high place and dug seven wells that were called Seven Wells. The second factor was that the site of Baqia Cemetery was selected on the Southeastern side behind the prevailing southwest winds of Medina. Furthermore, the edge of cemetery being adjacent to the mosque was several meters higher and declined to the southeast with a reverse slope. This prevented the leaching of cemetery contaminants to the mosque during precipitation. The other factor was that there were some palms, a number of pagans' graves and a dilapidated building in a closed site that Prophet had selected for the mosque, So, Prophet ordered to prepare the land for the building of the mosque $(9: 28)$, Immigrants and the Ansar cut out all palm trees and cleaned the graves' ruins.

\section{9) Location with regard to its comprehensive function}

Despite the unpretentious and elementary structure of $\mathrm{Nabi}$ Mosque, mosque of Prophet (SAW) was a social institution to serve the people from the beginning which made this center quickly grow and evolve into a multi-purpose complex [40]. This accomplishment was because of utilizing the capacity of maintaining public community, offering a comprehensive plan to establish, equip and optimize functions of mosque, objectivity of association between religion and politics in Nabavi government. Thus, a relationship with God, community and nation was on the agenda and created a permalink between the mosque and community and its related affairs. Prophet named the mosque in the name of Nabi Mosque and corresponded with the heads of Rome and Iran Empire from this location with a comprehensive and powerful base support and robust international affairs. In the beginning of the letters he wrote: "I Prophet Mohammed to... .

\section{RESULT}

In determining the location of Nabi Mosque, it can be concluded that all of the aspects of location process were important starting with the aim of virtue and continuing to planning, design and mosque construction. This process leads to pure results in order to serve the people and then finishes with a balanced mix of principles and values of Islam. Prophet Mohammed's era represents the first and most decisive phase of promoting the identity of Islamic architecture ever known. What the Prophet taught as the foundation of Islamic architecture was the introduction of the conceptual and ideological hidden aspects that was uncovered in different fields such as architecture and urban planning aspects of Islamic civilization, later. Ethereal aspect of Islamic architecture, due to the requirements of that era, had physical, rigid and simple form at the time of Prophet but Prophet's role in promoting the phenomenon of Islamic architecture became more obvious with the evolution of $\mathrm{Nabi}$ Mosque. In accordance with the orders of the verses and Hadithes with Prophet's Sira in Nabi Mosque's location as the pattern of Islamic mosques, it should be said that almost all of God's orders for building mosques were followed by Prophet Mohammed including pure faith, prosperity and development, relaxation, dominance to city, establishment in a clean environment, development possibility, availability (centrality) and etc. On the other hand, there were some criteria that had affected Nabi Mosque location the same as geographical, political, social, and cultural conditions that were in accordance with Prophet Mohammed's Sira including tribal system, dry weather, primitive architecture, integrity necessity of Nabi Mosque, and etc.

\section{CONCLUSION}

The most important aspects of his teachings in locating today's mosques can also include:

1) Classification of mosques to neighborhood, community, district and regional ones to:

- Reconciling with the rate of population and functions with land of mosque. 
- Coordination of land allocated to classified mosques for development possibility in the future.

- Creating hierarchy of access appropriate with city context.

- Choosing location with regard to mosque dependent functions of classified mosques (for local mosques and commercial, sport - cultural functions and for regional mosques, a multi-purpose halls).

- Coordination with the city context that can meet its requirement and promote its indigenous style and history.

2) Designer selection by professional consulting engineers and religious authorities as well.

3) Choosing location in order to promote the prosperity of mosques with factors such as:

- Placement in population centers, nodes, urban paths and crowded environments.

- Choosing location in secure lands, in addition to checking their assessing the risk (away from watercourse, faults and thrust).

- Surveying compatible proximities (Promoting worship role of Mosque) and incompatible ones (Eliminating them such as hazardous industries and petrol stations).

- Location in scenic environment.

4) Location with regard to its worship dominant function

A: location with the aim of proximity to nature.

- Attention to devotion in site selection of mosque and assigning it only for worship and considering adjacent lands for mosque dependent functions.

- Attention to unity of additional, main and auxiliary spaces in mosque location.

- Attention to correct mapping and careful selection of Qiblah, and giving centrality to worship spaces and putting them on the axis that are perpendicular to the Qiblah wall in location and considering entrance of mosque on that axis avoid being behind Qiblah.

- Considering a space for religious-cultural ceremonies in location not to interfere with worship function.

5) Maintaining the cleanliness of the mosque:

- Mosque location higher than its service functions, particularly than engine room and Ablution places. It is better to locate WC with a certain distance of Seven Steps from worship place for shoes to get cleaned.

- Mosque location in clean environment with clean air.

- Mosque location away from noise pollution.

- Location of WC with a reverse slope of the land, to flow its water away from worship place.

- Mosque location with possibility of radiation of natural light and ventilation.

- Due to the distance between neighboring walls and mosque wall specially Qiblah wall in worship place, following points should be noted:

6) Neighborhood's rights Observance.

- A: Avoiding usurpation of land for mosque.

- Preventing from the possibility of observing inside the private spaces from any place of mosque.

- Location of public spaces of mosque in its heart to reduce noise pollution and neighbor teasing.

7) Location of mosque for crisis management.

- Predicted rapid access to all areas of the city from the main way in risk situations.
- Suitability location structurally.

- Locating of mosque with possibility of using it as a shelter

- Choosing correct location of engine room and avoid locating it in the basement.

- Checking the risk of surrounding buildings.

\section{ACKNOWLEDGMENT}

Fatima Jalilzadeh Mohammadi and Parisa Ghorbannejad as author of this research thank Dr. Spahich Omer, Dr. Ahmad Aminpoor, Dr. Armin Bahramian, and Dr. Mahmood Mahmoodi.

\section{REFERENCES}

[1] A. Bayhaqi, Dalail On-Nobvva, A Isfahani trans, Tehran, Cultural Academic Press, 1982, p. 18.

[2] M. A. J. A. Shanghiti, A. Azvaa' ol-Bayn fi Izah il-Gora'ni bil-Ghora'n. Beiroot, Dar ol-Fikr, 2009, p. 256.

[3] M. A. Ameli, Vasail osh-shiah ila Tahsil Masail ish-Shariah, Teharn, Maktabat ol-Islamiah, 1993.

[4] A. A. Tabarani, Mojam ol-Kabir, Beirut: Dar Al-Kotob el-Elmiah, without Publication History, 1990, vol. 3, p.19.

[5] M. A. Hamedani, M. Hamzehnejad, and M. N. Abdolhamid, "A study about the location of mosques in medina during the era of Prophet Mohammed (PBUH) (an introduction to principles for determining proper locations for mosques in Islamic cities)," Nazar Garden, vol. 16, pp. 3-16, January 2011.

[6] A. M. Hindi, Kanz Ol-Ommal Fi Sonan IL-Aghval V Al-Afa'al, Beirut: Dar Al-Fikr, 2010, vol. 7, p. 653.

[7] M. S. Javahir, Javahir ol-Kalaam fi Shahi Sharayi il-Islam, Beirut: Dar ol-Ihyaa' it-Toras il-Arabi, 1983, p. 47.

[8] M. A. Hamedani, M. Hamzehnejad, and M. N. Abdolhamid, "A study about the location of mosques in medina during the era of Prophet Mohammed (PBUH) (an introduction to principles for determining proper locations for mosques in Islamic cities)," Nazar Garden, vol. 16, pp.3-16, 2011.

[9] E. Qureshi, Tafsir ol-Ghoran Tafir bin Kathir. Riyadh: Dar ot-Tayyeba, 2000, p. 120.

[10] A. Mottaghi, Hindi, Kanz ol-Ommal fi Sonan il-Aghval v al-Afa'al, Beirut: Dar Al-Fikr, 2010, vol. 9, p. 288.

[11] M. Al-Bukhari Aljafee, Sahih Bukhari, Beirut: Al-Nida Al-Iman, 2013, p. 422.

[12] S. A. A. A. S. A. Dawood, Sunan Abu Dawood, Shoaib Arnaout. Beirut: Dar Al-Risalah Al-alamiah, 2008, vol. 1, p. 423.

[13] A. A. Kanani, Fath ol-Bari fi Sharh Sahih el-Bokhari, Cairo: dar ar-Riyan li-Toras, 1985, p. 458.

[14] E. Groobe, Muslim Architecture, History, and Social Context, Y. Ajand Trans. Teharn: Mola Publisher, 2000, p. 210.

[15] R. Hillenbrand, Islamic architecture: Form, Function, Meaning. B. Shirazi rans. Teharn, Stomata Pub, 2001, p. 68.

[16] J. Suyuti, Dor Ol-Manthor Fi Tafsiri Bil-Maa'thur, Beirut: Dar Al-Kotob el-Elmiah, 1999, vol. 6, p. 203.

[17] R. Hillenbrand, Islamic architecture: Form, Function, Meaning, B. Shirazi rans. Teharn, Stomata Pub, 2001, p. 39.

[18] M. T. Rasdi and M. Z. M. Taib, "Islamic architecture evolution: perception and behaviour," presented at 1st National Conference on Environment-Behaviour Studies, Faculty of Architecture,Planning \& Surveying .Selangor, Malaysia: Procedia - Social and Behavioral Sciences 49-Elsevier, pp. 293-303, 2012.

[19] R. Hillenbrand, Islamic architecture: Form, Function, Meaning, B. Shirazi Rans. Teharn, Stomata Pub, 2001, p. 40.

[20] R. Ettinghausen and O. Grabar, Islamic Art and Architecture, Y. Ajand Trans. Tehran, Samt, 2004, pp. 5-6.

[21] E. Groobe, Muslim Architecture, History, and Social Context, Y. Ajand trans, Teharn: Mola Pub, 2000, p. 210.

[22] A. Kaa'ki, Maa'lim ol-Madinat ol-Monavvara Bayn al-Imarat $v$ at-Tarikh. Beirut: Dar v al-Maktabat ol-Hilal, 2002, p. 62.

[23] H. Hasani, Sirat ol-Mostafa, Tehran: Wisdom pub, 1991, p. 17.

[24] A. A.Zuhri, At-Tabaghat ol-Kobra.vol. 3, Beirut: Dar ol-Kotob il-Ilmiyya, 1985, p. 37.

[25] M. Saharaab, Geographical's Culture-History in Prophet Mohammed's Sira, H.Sheikhy trans. Tehran: Mash a'ar, 2004, p. 350.

[26] A. Gha'edan, "Architecture of mosques and buildings of Prophet's (PBUH) era,” Hajj Rendezvous, vol. 59, pp. 144-120, 2007. 
[27] A. Sahmudi, Vafa $a^{\prime}$ ol-Vafa a' bi a'akhbair Dar ol-Mostafa. Beirut: Dar ol-Koto il-Ilmiyya, 2000, p. 249.

[28] A. Haumeiri, As-Sirat on-Nabaviyya., Beirut: Dar ol-Maarifa, without Publication History, Ibn Battuta's Itinerary, Tehran: Agah pub, vol. 1, pp. 154-155, 1997.

[29] M. A. Hamedani, M. Hamzehnejad, and M. N. Abdolhamid, "A study about the location of mosques in medina during the era of Prophet Mohammed (PBUH) (an introduction to principles for determining proper locations for mosques in Islamic cities)," Nazar Garden, vol. 16, pp. 3-16, 2011.

[30] M. S. Shami, Sobol al-Hoda v ar-Rashaad. Beirut, Dar ol-Koto il-Ilmiyya, 1992, vol. 3, p. 42.

[31] A. Gha'edan, "Architecture of mosques and buildings of Prophet's (PBUH) era," Haij Rendezvous, vol. 59, pp. 144-120, 2007.

[32] M. A. B. Aljafee, Sahih Bukhari, Beirut: Al-Nida Al-Iman, 2013, p. 233

[33] A. Kaa'ki, Maa'lim ol-Madinat ol-Monavvara Bayn al-Imarat $v$ at-Tarikh. Beirut: Dar v al-Maktabat ol-Hilal, 1998, p. 62.

[34] S. S. Dlmuji, Medina Prophetic Shrine, Tehran:Mash a'ar, 1998, p. 18

[35] M. Majlisi, Medina Science, Tehran:Mash a'ar, 2007, vol. 1, p. 32.

[36] S. H. R. Mahallati, Life of Prophet Mohammed "PBUH", Isfahan: Ahl al-Bayt (AS) Institute for Islamic Research and Publication, 1994, p. 264.
[37] A. Papadopolo, Islamic Architecture, H. Jazni trans. Tehran: Cultural Publication of Raja, 1989, p. 11.

[38] M. Tuna, Hajj Encyclopedia,Ghom:Famous pub, 2011. p. 53.

[39] A. Kaa'ki, Maa'lim ol-Madinat ol-Monavvara Bayn al-Imarat $v$ at-Tarikh, Beirut: Dar v al-Maktabat ol-Hilal, 1998, p. 78.

[40] S. Omer, "Some lessons from prophet mohammed (SAW) in architecture: the Prophet's Mosque in MadÊnah" Intellectual Discourse, vol. 18, pp. 115-140, 2010.

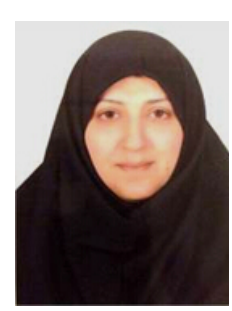

Parisa Gorbannejad is a scientific board member and an assistant professor in history and civilization of Islamic nations, Urmia Free University, West Azerbaijan, Iran. She was born in Urmia Iran in 1971. She has graduated in PhD-Islamic history and civilization in Islamic Azad University-Science and Research in 2005

Parisa's most important work experiences include teaching Islamic history and Islamic culture and civilization in Islamic Azad University of Urmia. In addition she has 35 articles and 4 Research Projects and has guided more than 30 theses. 